\title{
Chemical fractions and phytoavailability of copper to rape grown in the polluted paddy soil
}

\author{
H. F. Yang $\cdot$ Y. B. Wang $\cdot$ Y. J. Huang
}

Received: 19 February 2012/Revised: 1 October 2014/Accepted: 22 October 2014/Published online: 5 November 2014

(C) Islamic Azad University (IAU) 2014

\begin{abstract}
This paper focuses on the phytoaccumulation and translocation of copper $(\mathrm{Cu})$ in rape grown in the $\mathrm{Cu}$ polluted paddy soil. Pot experiments were conducted in greenhouse conditions to examine the $\mathrm{Cu}$ availability and uptake by rape in a paddy soil. The soil was spiked with different concentrations of $\mathrm{Cu}(0,100,300,500$ and $1,000 \mathrm{mg} \mathrm{kg}^{-1}$ soil, added as $\mathrm{CuSO}_{4}$ ) to simulate soil $\mathrm{Cu}$ contamination. After 8 months of growth, plant shoots, stems, pod shells and rapeseeds were harvested for analysis. The concentrations of $\mathrm{Cu}$ in the roots and aerial parts of the rape and available $\mathrm{Cu}$ in soils were then extracted and determined. Chemical fractions of $\mathrm{Cu}$ in the paddy soil of rape were also investigated by sequential extraction techniques. The findings showed that $\mathrm{Cu}$ in the clean paddy soil was mainly distributed in residual fractions. However, the most drastic increase was observed in $\mathrm{Fe}-\mathrm{Mn}$ oxidesbound fractions and organic-bound fractions with increasing soil $\mathrm{Cu}$ concentrations. Exchangeable fractions played a more important role than other fractions in controlling the mobility and phytoavailability of $\mathrm{Cu}$. Rape growth was stimulated by low concentrations of $\mathrm{Cu}$, but inhibited by high concentrations. Compares to the aerial parts, the roots were more sensitive to $\mathrm{Cu}$ toxicity. The correlation analysis showed that $\mathrm{Cu}$ in exchangeable fractions made the greatest contribution on the accumulation of $\mathrm{Cu}$ in rapes. The factor analysis results showed that the exchangeable fractions in roots can be indicator of $\mathrm{Cu}$ availability. Meanwhile, the bio-concentration factors and the translocation factors of $\mathrm{Cu}$ in rape were determined and the results
\end{abstract}

H. F. Yang $(\bowtie) \cdot$ Y. B. Wang · Y. J. Huang

College of Life Science, Anhui Normal University, 1 East Beijing Road, Wuhu 241000, Anhui, People's Republic of China e-mail: hongfeiy@mail.ahnu.edu.cn showed that $\mathrm{Cu}$ had lower accumulation in the edible parts of the rape.

Keywords Brassica napus L. · Chemical fractionation . Copper accumulation $\cdot$ Factor analysis $\cdot$ Phytoaccumulation

\section{Introduction}

Rape (Brassica napus L.) is one of the most important staple oil crops in a large part of the world, especially in China. Because of increased input from industry, traffic and agriculture, the average heavy metal content in soils has increased considerably (Salomons and Stigliani 1995). Heavy metal contamination in soil is a major problem for the environmental quality of the world (Yoon et al. 2006). Copper is an essential nutrient for plant growth at low concentrations, but excessive amounts are phytotoxic (Michaud et al. 2007).

The paddy soil is widely distributed in China, especially in the middle and lower reaches of Yangtze river, accounting for $1 / 5$ of the cultivated land of China. In recent years, due to irrigation by wastewater coming from the industry and agriculture activities, some paddy soils have been polluted by heavy metal, containing $\mathrm{Cu}$ pollution. It will cause a serious threat to ecological environment and human health (Luo et al. 2003). In order to avoid the $\mathrm{Cu}$ pollution of the food chain, it is essential to assess $\mathrm{Cu}$ bioavailability in paddy soil. Furthermore, the bioavailability of $\mathrm{Cu}$ to rape in the paddy soil in middle and lower reaches of Yangtze River of China has not been reported. Therefore, there is significance to research the uptake of $\mathrm{Cu}$ by rape under $\mathrm{Cu}$ contamination.

In order to evaluate $\mathrm{Cu}$ activity in soil and to determine how readily $\mathrm{Cu}$ uptake by plants occur, it is essential to 
understand its mobility and bioavailability which depends on its chemical fractionations in the soil, rather than on the total amount accumulated (Zemberyova et al. 1998; Tao et al. 2003). In soil matrix, $\mathrm{Cu}$ can be associated with soil components and exist in a variety of chemical-physical forms including exchangeable fraction, Fe-Mn oxidebound fraction, carbonate-bound fraction, organic-bound fraction and residual fraction in soils (Ahumada et al. 2009). There are different abilities to retain or release $\mathrm{Cu}$ in these fractions, as a result, it significantly influence the $\mathrm{Cu}$ mobility and bioavailability (Kabala and Singh 2001). Sequential extraction technique provides a powerful tool for evaluating metal forms (Tessier et al. 1979; Grzebisz et al. 1997). It has been used to estimate the distribution and potential bioavailability of $\mathrm{Cu}$ in soil (Maiz et al. 2000; Chaignon et al. 2003). Tessier's sequential extraction method has been widely used, in which heavy metals in soils were categorized in the five fractions: exchangeable fraction, carbonate-bound fraction, Fe-Mn oxide-bound fraction, organic-bound fraction and residual fraction (Tessier et al. 1979; Lucho-Constantino et al. 2005; Silveira et al. 2006; Rodríguez et al. 2009). Exchangeable fraction is bioavailable fractionation; carbonate-bound fraction, Fe-Mn oxide-bound fraction and organic-bound fraction are potential bioavailable fractionation; residual fraction is unbioavailable fractionation (Ma and Rao 1997; Rodríguez et al. 2009; Yang et al. 2011a).

Much work has been conducted to evaluate the availability, accumulation and translocation of $\mathrm{Cu}$ in the crops, such as rape, wheat and maize, to reduce $\mathrm{Cu}$ uptake by crops plants in $\mathrm{Cu}$-polluted soils (Tao et al. 2003; Herrero et al. 2003; Chaignon et al. 2009; Guan et al. 2011). Previous studies have focused on plant physiological responses and $\mathrm{Cu}$ accumulation in $\mathrm{Cu}$-contaminated soils (Johansson et al. 2005; Huang et al. 2009; Feigl et al. 2013). Other researches have showed that plant cultivation could increase the potentially available fraction of $\mathrm{Cu}$ in a polluted soil (Tao et al. 2003; Cattani et al. 2006). In addition, Brun et al. (2001) investigated the availability of $\mathrm{Cu}$ in $\mathrm{Cu}$-contaminated vineyard soils and measured changes in the concentrations of $\mathrm{Cu}$ in the roots and aerial parts of the maize. Ali et al. (2011) also have researched on the remediation methods for arsenic removal from the ground water. However, further studies are still crucially important because the processes in soil are very complex and need more evaluation.
The factor analysis (FA) is a more adequate multivariable technique when the goal is not only to reduce the number of variables but also to detect structures in the relationships between variables (Maiz et al. 2000). In the present paper, we have tried to evaluate the metal availability from polluted soil to rape growing in greenhouse conditions. The total metal content in soil and the fractions obtained with the sequential extraction procedure, and the ones found using the Tessier method were considered in the analysis. FA was used to check the relationships between metal contents in rape and the different fractions in paddy soil.

The primary objective of this study was to investigate copper fractionation in the soil in an attempt to obtain a better understanding of its availability and subsequent uptake by rape. Meanwhile, the bioavailability and translocation of $\mathrm{Cu}$ in rape grown in the $\mathrm{Cu}$-polluted paddy soil was also evaluated by a pot experiment in the current study. The research was carried out in Wuhu city within March 2006 to May 2007.

\section{Materials and methods}

\section{Soil samples}

The soil sample used in the study was collected from a paddy field of Qingshui in Wuhu city, Anhui province, China $\left(118^{\circ} 48^{\prime} \mathrm{E}, 31^{\circ} 30^{\prime} \mathrm{N}\right)$. Soil samples were collected from 60 randomly selected sites in the paddy field at 0-20 cm depth. The main properties of soil are shown in Table 1. The total $\mathrm{Cu}$ concentration was in the range of the national environmental quality standard for agricultural soils (Cu $50 \mathrm{mg} \mathrm{kg}^{-1}$ in GB 15618-1995) issued by State Environmental Protection Agency of China.

\section{Experimental design}

The soil samples were air-dried and passed through a 2-mm sieve prior to the greenhouse pot experiment. Chemical fertilizers, at the rates equivalent to $0.3 \mathrm{~g} \mathrm{~N}, 0.2 \mathrm{~g} \mathrm{P}$ and $0.3 \mathrm{~g} \mathrm{~K} \mathrm{~kg}^{-1}$ (dry weight) were applied as $\left(\mathrm{NH}_{4}\right)_{2} \mathrm{SO}_{4}$, $\mathrm{KH}_{2} \mathrm{PO}_{4}$ and $\mathrm{K}_{2} \mathrm{SO}_{4}$, were mixed with 5-kg air-dried soil (bulk soil) thoroughly in plastic pots $(28 \mathrm{~cm}$ in height and $22 \mathrm{~cm}$ in diameter) before sowing. The experiment totally contained five treatments. The five treatments had been

Table 1 Physical and chemical properties of soil samples

\begin{tabular}{lllllll}
\hline $\begin{array}{l}\text { Soil } \\
\text { type }\end{array}$ & $\mathrm{pH}$ & $\mathrm{EC}$ & $\begin{array}{l}\text { Organic matter } \\
\left(\mathrm{g} \mathrm{kg}^{-1}\right)\end{array}$ & $\begin{array}{l}\text { Total N } \\
\left(\mathrm{g} \mathrm{kg}^{-1}\right)\end{array}$ & $\begin{array}{l}\text { Total P } \\
\left(\mathrm{g} \mathrm{kg}^{-1}\right)\end{array}$ & $\begin{array}{l}\text { Total K } \\
\left(\mathrm{g} \mathrm{kg}^{-1}\right)\end{array}$ \\
\hline $\begin{array}{l}\text { Paddy } \\
\text { soil }\end{array}$ & $7.32 \pm 0.47$ & $98 \pm 9$ & $17.22 \pm 2.10$ & $1.68 \pm 0.17$ & $0.34 \pm 0.09$ & $\begin{array}{l}\text { Total Cu } \\
\left(\mathrm{mg} \mathrm{kg}^{-1}\right)\end{array}$ \\
\hline
\end{tabular}


spiked with a series of $\mathrm{Cu}^{2+}$ concentration $(0,100,300$, 500 and $1,000 \mathrm{mg} \mathrm{kg}^{-1}$ soil, added as $\mathrm{CuSO}_{4}$ ), and watered and left to equilibrate outdoors for 2 weeks before planting vegetables. All the treatments were arranged in a complete random design with four replicates. Thirty seeds of rape named Huyou 16 (Brassica napus L.) were sowed in each pot, and the seedlings were thinned triple to the total of 10 in each pot. After cultivation for 45 days, the seedlings were thinned to the total of 3 in each pot. The moisture content of $60 \%$ field water holding capacity was adjusted by weight during rape growth. Rape plants were harvested at mature stages (after 8 month) for analysis.

Soil and plant sampling

At the termination of the cultivation period, rape plants were harvested and soil samples were collected from the rhizosphere for fractionation. The soil samples were airdried, ground and sieved to $2 \mathrm{~mm}$ for the analysis of available $\mathrm{Cu}$, total $\mathrm{Cu}$ and $\mathrm{Cu}$ fractions. The plant samples were washed with running tap water and rinsed thoroughly with deionized water, dried at $70{ }^{\circ} \mathrm{C}$ for $24 \mathrm{~h}$, and dry masses were recorded before copper determination. The dried plant samples were used for biomass determination, and then, they were stored in desiccators for total $\mathrm{Cu}$ analysis after being ground and sieved to $0.25 \mathrm{~mm}$.

\section{Analytical methods}

The dried plant samples were digested by $\mathrm{HNO}_{3}-\mathrm{H}_{2} \mathrm{SO}_{4}-$ $\mathrm{HClO}_{4}$ (8:1:1) after being triturated, and the concentrations of $\mathrm{Cu}$ were determined by atomic adsorption spectrophotometry (AA6800, Shimadzu, Japan); the $\mathrm{Cu}$ standard sample of the State Environmental Protection Agency of China was used for correction (Environmental Monitoring of China 1992). According to the sequential fractionation method, a proportion of liquid to soil of 10:1 was made for $\mathrm{Cu}$ fraction extraction. The sequential extraction method of Tessier et al. (1979) was used for the $\mathrm{Cu}$ fractions. Soil $\mathrm{pH}$ and the contents of water-soluble salts, organic matter and $\mathrm{N}$, $\mathrm{P}$, and $\mathrm{K}$ were measured by the methods of Environmental Monitoring of China (1992). Soil samples were extracted by $0.1 \mathrm{~mol} \mathrm{~L}^{-1} \mathrm{HCl}$ (liquid:soil = 5:1) for $90 \mathrm{~min}$, to determine the concentration of available $\mathrm{Cu}$ in soils. The content of $\mathrm{Cu}$ was determined by atomic adsorption spectrophotometer (AAS) [AA6800, Shimadzu, Japan]. All chemicals were of analytical grade, and all plastic and glassware were washed before use, soaked in $2 \% \mathrm{HNO}_{3}$ for more than $24 \mathrm{~h}$, and rinsed with deionized water.
Statistical analysis

All results were reported as the mean of four replicates, and all data were subjected to one-way analysis of variance with SPSS 13.0 statistics software. Regression, correlation analysis and $t$ test were used to determine the significance of difference among various groups of plant and soil samples.

\section{Results and discussion}

Chemical fractions distribution of $\mathrm{Cu}$ in soil

Figure 1 shows that $\mathrm{Cu}$ chemical fractions contents all increased with addition of any $\mathrm{Cu}$ treatment in soil. With increasing $\mathrm{Cu}$ concentrations in paddy soils, the concentrations of $\mathrm{Cu}$ in $\mathrm{Fe}-\mathrm{Mn}$ oxides-bound fractions, organicbound fractions and residual fractions increased greatly, relative to the control, while the exchangeable fractions and carbonate-bound fractions in soils increased indistinctively in $0 \mathrm{mg} \mathrm{kg}^{-1}$ treatment and $100 \mathrm{mg} \mathrm{kg}^{-1}$ treatment. With the growth of rape in soils, the concentrations of $\mathrm{Cu}$ in exchangeable fraction was more than carbonate-bound fraction in $500 \mathrm{mg} \mathrm{kg}^{-1}$ treatment and $1,000 \mathrm{mg} \mathrm{kg}^{-1}$ treatment, whereas the relationship was reversed for lower concentration treatment groups. The parameter fractionation distribution coefficient (FDC) was usually defined as the one metal fractionation content accounting for the percentage by total amount of the same

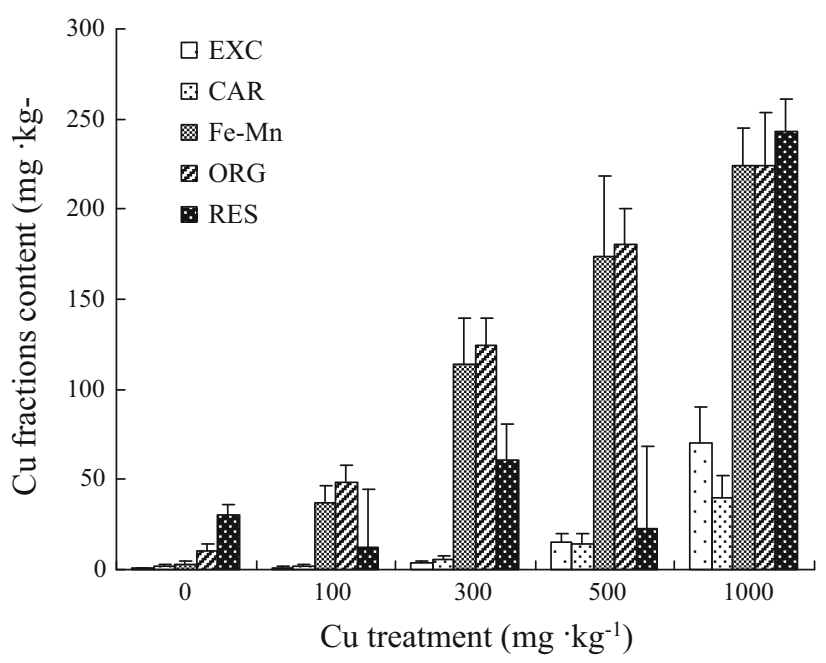

Fig. 1 Distribution of $\mathrm{Cu}$ fractions in the paddy soil in which rape was grown for 8 month. EXC the exchangeable fractions, CAR the fraction associated with carbonates, $\mathrm{Fe}-\mathrm{Mn} \mathrm{Fe}-\mathrm{Mn}$ oxides-bound fractions, $O R G$ the fraction associated with the organic matter and/or sulfides, RES the residual fraction 


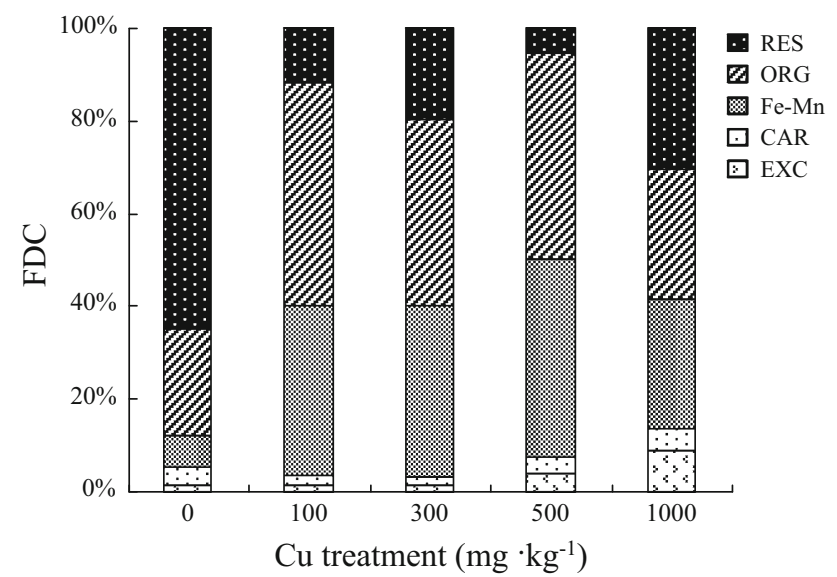

Fig. 2 Fraction distribution coefficient (FDC) of $\mathrm{Cu}$ in the paddy soil in which rape was grown for 8 month. Values were means of four replicates. EXC the exchangeable fractions, $C A R$ the fraction associated with carbonates, $\mathrm{Fe}-\mathrm{Mn} \mathrm{Fe}-\mathrm{Mn}$ oxides-bound fractions, $O R G$ the fraction associated with the organic matter and/or sulfides, $R E S$ the residual fraction

metal. The FDCs of $\mathrm{Cu}$ increased significantly in $\mathrm{Fe}-\mathrm{Mn}$ oxides-bound and organic-bound $(P<0.001)$ with increasing soil $\mathrm{Cu}$ concentration $\left(0-500 \mathrm{mg} \mathrm{kg}^{-1}\right)$ probably because of greater mobility of $\mathrm{Cu}$ in the paddy soil. However, FDCs of $\mathrm{Cu}$ in $\mathrm{Fe}-\mathrm{Mn}$ oxides-bound and organic-bound decreased partly, when soil $\mathrm{Cu}$ concentration reached $1,000 \mathrm{mg} \mathrm{kg}^{-1}$. FDC of $\mathrm{Cu}$ reduced significantly in residual fraction $(P<0.001)$, in range of $0-500 \mathrm{mg} \mathrm{kg}^{-1}$. However, FDC of residual fraction increased obviously when soil $\mathrm{Cu}$ concentration reached $1,000 \mathrm{mg} \mathrm{kg}^{-1}$, compared to 100,300 and $500 \mathrm{mg} \mathrm{kg}^{-1}$ treatment. FDCs of $\mathrm{Cu}$ in exchangeable fraction and carbonate-bound fraction did not rise significantly until soil $\mathrm{Cu}$ concentration reached 500 and $1,000 \mathrm{mg} \mathrm{kg}^{-1}$ (Fig. 2).

In the sequential extraction procedure, exchangeable, carbonate-bound, $\mathrm{Fe}-\mathrm{Mn}$ oxides-bound, organic-bound and residual $\mathrm{Cu}$ were partitioned, respectively. Previous studies showed that in the clean soil, residual fractions was mainly heavy metals fraction, which was unbioavailable for the plants (Guo and Zhou 2005; Yang et al. 2011b), but the percentage of heavy metals associated with available fraction increased with increasing total amount of heavy metals (Guo and Zhou 2005). It was in agreement with the results obtained in present study. In the present study, $\mathrm{Cu}$ was primarily accumulated in the residual fractions $(64.72 \%)$ and organic-bound fractions $(23.02 \%)$ in bulk soil (the control), indicated that $\mathrm{Cu}$ had stronger ability to associate with the crystalline structures of the minerals and the organic ligand (Fuentes et al. 2004; Guan et al. 2011). The results showed that residual fractions were mainly $\mathrm{Cu}$ fraction in unpolluted paddy soil, however, with the increase in amounts of $\mathrm{Cu}$ in the soil, bioavailable fractions increased significantly. A series of interactions (e.g., adsorption, precipitation, complexation, etc.) would take place with the extraneous $\mathrm{Cu}$ addition. $\mathrm{Cu}$ was primarily adsorbed to the strongest binding sites such as soil organic matter and accumulated in organic-bound fractions (Cao and $\mathrm{Hu}$ 2000; Marcato et al. 2009; Guan et al. 2011). The $\mathrm{Cu}$ in soil was firstly precipitated at the stronger competitive sites as $\mathrm{Fe}$ and $\mathrm{Mn}$ oxides and then at weaker sites such as carbonates (Cao and $\mathrm{Hu}$ 2000). Therefore, the $\mathrm{Fe}-\mathrm{Mn}$ oxides-bound fractions increased most drastically with increased soil $\mathrm{Cu}$ concentrations. $\mathrm{Cu}$ chemical fractions in soil were dependent on $\mathrm{Cu}$ addition. When $\mathrm{Cu}$ addition was higher than $100 \mathrm{mg} \mathrm{kg}^{-1}$, the residual fractions significantly declined but the $\mathrm{Fe}-\mathrm{Mn}$ oxides-bound and organic-bound fractions increased markedly. The results suggested that the cultivation of the rape in paddy soil can induce the transformation of bound $\mathrm{Cu}$ from less mobile fractions to bioavailable fractions.

The biomass of rape tissues and the $\mathrm{Cu}$ uptake

\section{The biomass of rape tissues}

The change tendency of plant height and root length and fresh weight of rapes roots, stems, pod and rapeseeds under $\mathrm{Cu}$ treatments are shown in Table 2. The plant height of rape increased to a certain extent $(86.30 \mathrm{~cm}$ at $100 \mathrm{mg}$ $\mathrm{kg}^{-1} \mathrm{Cu}$ addition) and then significantly decreased with the increased $\mathrm{Cu}$ addition (Table 2). The addition of $\mathrm{Cu}$ obviously inhibited the root elongation of rape in paddy soils, compared to the control $\left(0 \mathrm{mg} \mathrm{kg}^{-1}\right)$. Table 2 also shows the fresh biomass of rape roots, stems, pods and rapeseeds under $\mathrm{Cu}$ treatments. The fresh biomass of rape stems increased to a certain extent $\left(9.76 \mathrm{~g}\right.$ at $100 \mathrm{mg} \mathrm{kg}^{-1}$ $\mathrm{Cu}$ addition) and then significantly decreased with the increased $\mathrm{Cu}$ addition, it indicated that this value $(100 \mathrm{mg}$ $\mathrm{kg}^{-1} \mathrm{Cu}$ addition) was hazardous threshold of rape. The fresh biomass of roots and pods decreased significantly with the increased $\mathrm{Cu}$ addition. However, the fresh biomass of rapeseeds increased till the $\mathrm{Cu}$ addition at $300 \mathrm{mg} \mathrm{kg}^{-1}$ and the magnitude was $0.17 \mathrm{~g}$. Afterward, the fresh biomass decreased significantly to $2.40 \mathrm{~g}$ for stems and $0.07 \mathrm{~g}$ for rapeseeds when $\mathrm{Cu}^{2+}$ was added at $1,000 \mathrm{mg} \mathrm{kg}{ }^{-1}$. These results indicated that the toxic effect of $\mathrm{Cu}$ on rapes had threshold values. Rapes growth could be stimulated by low concentrations of $\mathrm{Cu}\left(\leq 100 \mathrm{mg} \mathrm{kg}^{-1}\right)$, but inhibited by high concentrations $\left(1,000 \mathrm{mg} \mathrm{kg}^{-1}\right)$. The results were consistent with reports that heavy metals influence root tip cell mitosis, decrease the rate of cell division, and cause biomass to decrease (Yang et al. 2002; Seregin and Kozhevnikova 2006). 
Table 2 Effects of $\mathrm{Cu}$ on the growth and matter accumulation of rape in different treatments

\begin{tabular}{|c|c|c|c|c|c|c|c|}
\hline \multirow{2}{*}{$\begin{array}{l}\text { Treatment (mg } \\
\mathrm{kg}^{-1} \text { ) }\end{array}$} & \multirow{2}{*}{$\begin{array}{l}\text { Plant height } \\
(\mathrm{cm})\end{array}$} & \multirow{2}{*}{$\begin{array}{l}\text { Root length } \\
(\mathrm{cm})\end{array}$} & \multicolumn{4}{|l|}{ Fresh weight } & \multirow{2}{*}{$\begin{array}{l}\text { Pod } \\
\text { number }\end{array}$} \\
\hline & & & $\begin{array}{l}\text { Stem } \\
\left(\text { g plant }^{-1}\right)\end{array}$ & $\begin{array}{l}\text { Root } \\
\left(\mathrm{g} \text { plant }^{-1}\right)\end{array}$ & $\begin{array}{l}\text { Pod } \\
\left(\text { g plant }^{-1}\right)\end{array}$ & $\begin{array}{l}\text { Rapeseeds } \\
\left(\mathrm{g} \mathrm{pod}^{-1}\right)\end{array}$ & \\
\hline 0 & $80.70 \pm 2.30$ & $13.00 \pm 1.80$ & $7.63 \pm 1.12$ & $5.87 \pm 0.59$ & $45.10 \pm 2.74$ & $0.15 \pm 0.03$ & $82 \pm 6$ \\
\hline 100 & $86.30 \pm 3.50$ & $8.20 \pm 3.10$ & $9.76 \pm 0.75$ & $4.79 \pm 0.82$ & $27.61 \pm 2.19$ & $0.16 \pm 0.04$ & $78 \pm 4$ \\
\hline 300 & $78 \pm 2.70$ & $10.00 \pm 1.10$ & $4.66 \pm 0.78$ & $2.26 \pm 0.92$ & $20.12 \pm 1.72$ & $0.17 \pm 0.09$ & $39 \pm 5$ \\
\hline 500 & $67.40 \pm 2.50$ & $9.20 \pm 0.96$ & $6.83 \pm 0.53$ & $3.22 \pm 0.43$ & $14.57 \pm 0.77$ & $0.12 \pm 0.12$ & $47 \pm 6$ \\
\hline 1,000 & $45.90 \pm 1.90$ & $8.70 \pm 0.78$ & $2.40 \pm 0.32$ & $2.60 \pm 0.09$ & $6.91 \pm 0.59$ & $0.07 \pm 0.08$ & $31 \pm 3$ \\
\hline
\end{tabular}

Values are mean \pm standard deviation (SD) of four replication samples

Table $3 \mathrm{Cu}$ concentrations in rape tissues in different treatments and the transfer ratios in rape-soil system

\begin{tabular}{|c|c|c|c|c|c|c|c|c|c|}
\hline \multirow{2}{*}{$\begin{array}{l}\text { Treatment } \\
\left(\mathrm{mg} \mathrm{kg}^{-1}\right)\end{array}$} & \multicolumn{9}{|c|}{$\mathrm{Cu}$ concentrations in rape tissues $\left(\mathrm{mg} \mathrm{kg}^{-1}\right)$ and the transfer ratios } \\
\hline & Roots & $\mathrm{BCF}_{\text {root }}$ & Stems & $\mathrm{BCF}_{\text {stem }}$ & $\mathrm{TF}_{\text {Stem/root }}$ & Pods shell & $\begin{array}{l}\text { Pods } \\
\text { shell/stem }\end{array}$ & Rapeseeds & $\begin{array}{l}\text { Rapeseeds/ } \\
\text { pods shell }\end{array}$ \\
\hline 0 & $26.70 \pm 0.74$ & 0.57 & $25.35 \pm 0.59$ & 0.54 & 0.95 & $16.40 \pm 1.26$ & 0.65 & $8.10 \pm 0.77$ & 0.49 \\
\hline 100 & $74 \pm 4.20$ & 0.73 & $14.85 \pm 9.58$ & 0.15 & 0.20 & $15.20 \pm 4.41$ & 1.02 & $8.28 \pm 1.38$ & 0.54 \\
\hline 300 & $115.65 \pm 8.49$ & 0.37 & $24.85 \pm 7.27$ & 0.08 & 0.21 & $40.55 \pm 5.97$ & 1.63 & $14.13 \pm 0.77$ & 0.35 \\
\hline 500 & $267.85 \pm 11.95$ & 0.66 & $10.80 \pm 6.88$ & 0.03 & 0.04 & $47.85 \pm 6.17$ & 4.43 & $14.55 \pm 0.47$ & 0.30 \\
\hline 1,000 & $1001.65 \pm 53.20$ & 1.25 & $20.10 \pm 5.73$ & 0.03 & 0.02 & $21.3 \pm 3.79$ & 1.06 & $12.18 \pm 1.53$ & 0.57 \\
\hline
\end{tabular}

Values are mean \pm standard deviation (SD) of four replication samples

\section{Accumulation of $\mathrm{Cu}$ in rape tissues}

The amounts and distribution of $\mathrm{Cu}$ accumulated in rapes under different treatments are shown in Table 3. The $\mathrm{Cu}$ concentrations in roots increased significantly with increased soil $\mathrm{Cu}$ concentrations and the magnitude ranged from 26.70 to $1001.65 \mathrm{mg} \mathrm{kg}^{-1}$ (Table 3). However, in general, compared with the control, rape stems' $\mathrm{Cu}$ concentrations did not decrease significantly, with the increased soil $\mathrm{Cu}$ concentrations. The $\mathrm{Cu}$ concentrations in pods shell and rapeseeds increased by 2.92-folds and 1.80-folds, respectively, at the $\mathrm{Cu}$ level of $500 \mathrm{mg} \mathrm{kg}{ }^{-1}$. Afterward, the $\mathrm{Cu}$ concentrations decreased significantly to $21.30 \mathrm{mg} \mathrm{kg}^{-1}$ for pods shell and $12.18 \mathrm{mg} \mathrm{kg}^{-1}$ for rapeseeds, when $\mathrm{Cu}^{2+}$ was added at $1,000 \mathrm{mg} \mathrm{kg}^{-1}$.

Bio-concentration factor (BCF) was calculated as the ratio of $\mathrm{Cu}$ concentration in rape roots or aerial parts to the total concentration in soil. Table 3 shows $\mathrm{BCF}_{\text {root }}$ was more than 1.0 in $1,000 \mathrm{mg} \mathrm{kg}^{-1}$ treatment. As the time of rape growth, a number of $\mathrm{Cu}^{2+}$ entered into the tissues of rape roots. $\mathrm{TF}_{\text {stem/root }}$ gradually decreased with increased soil $\mathrm{Cu}$ concentrations. When the soil $\mathrm{Cu}$ concentration reached $1,000 \mathrm{mg} \mathrm{kg}^{-1}, \mathrm{BCF}_{\text {stem }}$ reached the minimum value (0.03), decreased by 17 -folds, comparing with the control. Rape (Brassica napus L.) showed a ability for preventing $\mathrm{Cu}^{2+}$ to enter into the aerial parts. The observed trend of changes in $\mathrm{BCF}_{\text {stem }}$ in different treatments also paralleled the changes in $\mathrm{TF}_{\text {Stems/roots }}$ (Table 3).

Different from roots, the concentrations of $\mathrm{Cu}$ in rape stems were in a narrow range. The values varied from 25.35 to $20.10 \mathrm{mg} \mathrm{kg}^{-1}$, but were not significantly influenced by $\mathrm{Cu}$ addition. The ratio of stems/roots was 0.95 in the least $\mathrm{Cu}$-containing soils $\left(0 \mathrm{mg} \mathrm{kg}^{-1}\right)$, but it declined to 0.02 after $1,000 \mathrm{mg} \mathrm{kg}^{-1} \mathrm{Cu}$ addition. When the soil $\mathrm{Cu}$ concentration reached $500 \mathrm{mg} \mathrm{kg}^{-1}$, the ratio of pods shell/stems reached the maximum value (4.43), increased by 6.82 -folds, comparing with the control. But the ratio of pods shell/stems was reduced obviously with the concentration of $\mathrm{Cu}$ increasing. Unlike the ratio of pods shell/stems, the ratio of rapeseeds/pods shell was in a narrow range. The values varied from 0.49 to 0.57 , but were not significantly influenced by $\mathrm{Cu}$ addition.

The $\mathrm{BCF}_{\text {root }}$ of $\mathrm{Cu}$ can imply the capability of Cu entry from soil to plant, and the values were less than 1.00 (in range of $0-500 \mathrm{mg} \mathrm{kg}^{-1} \mathrm{Cu}$ addition), suggesting that only a small portion of $\mathrm{Cu}$ was transferred into the rape while large amount was still accumulated in soil. It indicated that just a small amount of copper had transferred into the aerial parts, the majority of copper had retained in root. That is to say, rape appeared to be capable of limiting $\mathrm{Cu}$ 
Table 4 Correlation coefficient $(R)$ between chemical fractions of $\mathrm{Cu}$ in the paddy soil and concentrations of $\mathrm{Cu}$ in rape root, stem, pod and rapeseed

\begin{tabular}{|c|c|c|c|c|}
\hline $\mathrm{Cu}$ fractions & Root & Stem & Pod shell & Rapeseed \\
\hline $\mathrm{EXC}$ & $0.997 * *(P<0.001)$ & $-0.061(P=0.923)$ & $-0.092(P=0.884)$ & $0.281(P=0.647)$ \\
\hline CAR & $0.988 * *(P=0.002)$ & $-0.123(P=0.844)$ & $0.031(P=0.961)$ & $0.389(P=0.517)$ \\
\hline $\mathrm{Fe}-\mathrm{Mn}$ & $0.804(P=0.101)$ & $-0.322(P=0.597)$ & $0.497(P=0.394)$ & $0.772(P=0.126)$ \\
\hline ORG & $0.786(P=0.115)$ & $-0.333(P=0.583)$ & $0.519(P=0.370)$ & $0.789(P=0.113)$ \\
\hline RES & $0.941 *(P=0.017)$ & $0.211(P=0.733)$ & $-0.177(P=0.776)$ & $0.226(P=0.715)$ \\
\hline
\end{tabular}

* Significant at level $P<0.05$, ** significant at level $P<0.01$

translocation from soil to roots to avoid excessive $\mathrm{Cu}$ induced damage. The reason may be due to $\mathrm{Cu}$ fractions in the rhizosphere soil influenced by rape growth time. This resistance capacity may be attributed to the complexing agents from roots exudates could form stable complexes with $\mathrm{Cu}$ to decrease $\mathrm{Cu}$ bioavailability (Ahumada et al. 2009; Torri and Lavado 2009), and the root/mycorrhizal structures of rape could potentially limit the $\mathrm{Cu}$ uptake into the symplasm (Zhang et al. 2009). In addition, root-induced changes in dissolved organic carbon, redox potential and microbial activity in the rhizosphere may cause the change in copper fractionation (Tao et al. 2003), limiting the movement of $\mathrm{Cu}$. In line with some former investigations, $\mathrm{Cu}$ was found to accumulate more in the roots than in the aerial parts (Lexmond 1980; Brun et al. 2001; Chaignon et al. 2003; Ahumada et al. 2009; Guan et al. 2011). This has been described as a mechanism of plant tolerance to metal toxicity. The accumulation of metals in roots would minimize the adverse effects of metals on shoot growth (Chaignon et al. 2009); thus, metal sequestration in roots could be considered as a major adaptation of plants to metal stress (Clemens et al. 2002).

If the load of $\mathrm{Cu}$ was extremely high, e.g., greater than $500 \mathrm{mg} \mathrm{kg}^{-1}$, the resistance of roots to $\mathrm{Cu}$ declined drastically and the $\mathrm{Cu}$ accumulation in roots significantly increased. It was in agreement with the results obtained in present study where the $\mathrm{BCF}_{\text {root }}$ of $\mathrm{Cu}$ was more than 1.0 , when soil $\mathrm{Cu}$ concentrations reached $1,000 \mathrm{mg} \mathrm{kg}-1$ (Table 3). As shown in Table 3, the gradual decline of stems/roots ratios with increased $\mathrm{Cu}$ suggested that an important restriction occurred in the internal transport from roots to stems. The main enrichments of $\mathrm{Cu}$ in roots were evident in many cases, especially at higher $\mathrm{Cu}$ loading (Bhattacharyya et al. 2006; Ahumada et al. 2009; Guan et al. 2011). However, the resistant effect was limited when extremely large quantities of $\mathrm{Cu}$ were added. The rapeseeds/pod shells ratios showed the capability of $\mathrm{Cu}$ entry from pod shells to rapeseeds, and the values were less than 1.00 in all $\mathrm{Cu}$ treatments, suggesting
Table 5 Linear regression analysis between the available $\mathrm{Cu}$ content in soil and $\mathrm{Cu}$ contents in rape root, stem, pod shell and rapeseed

\begin{tabular}{lll}
\hline Regression equation & $R$ value & Significance \\
\hline $\mathrm{Y}_{\text {root }}=1.418 \mathrm{X}_{\text {available } \mathrm{Cu}}-71.150$ & 0.968 & 0.007 \\
$\mathrm{Y}_{\text {stem }}=-0.003 \mathrm{X}_{\text {available } \mathrm{Cu}}+19.933$ & 0.125 & 0.841 \\
$\mathrm{Y}_{\text {pod shell }}=0.01 \mathrm{X}_{\text {available } \mathrm{Cu}}+25.782$ & 0.176 & 0.777 \\
$\mathrm{Y}_{\text {seed }}=0.006 \mathrm{X}_{\text {available Cu }}+9.880$ & 0.535 & 0.353 \\
\hline
\end{tabular}

$\mathrm{Y}$ means $\mathrm{Cu}$ contents in rape root, stem, pod shell and seed; $\mathrm{X}$ means available $\mathrm{Cu}$ content in soil

that rape appeared to be capable of restricting $\mathrm{Cu}$ translocation from pod shells to rapeseeds to avoid excessive $\mathrm{Cu}$-induced damage.

\section{Relationships among $\mathrm{Cu}$ availability, $\mathrm{Cu}$ chemical fractions in soil and the uptake by rape}

The correlation analyses were performed among the $\mathrm{Cu}$ concentrations in rape tissues, available $\mathrm{Cu}$ and different chemical fractions of $\mathrm{Cu}$ in soil. As shown in Table 4, the $\mathrm{Cu}$ concentrations in roots presented significant correlation relationship with the EXC-Cu and CAR-Cu in soil $(R>0.90, P<0.01)$, respectively. Similarly, the Cu concentrations in roots also presented significant correlation relationship with the RES-Cu in soil $(R>0.90, P<0.05)$. However, no significant correlations were found between EXC- $\mathrm{Cu}$ and $\mathrm{Cu}$ concentrations among stems, pod shells and rapeseeds, except roots (Table 4).

Linear regression models were perfectly fitted between the $\mathrm{Cu}$ concentrations in rape tissues (as dependent variable) and $\mathrm{Cu}$ available fractions in soil (as independent variables). Table 5 shows the $\mathrm{Cu}$ available fractions were significantly related with the $\mathrm{Cu}$ in roots with $R$ higher than $0.90(P<0.01)$. The $\mathrm{Cu}$ concentrations in stems, pod shells and seeds exhibited weaker relations with the concentrations of $\mathrm{Cu}$ available fractions for $R$ was $0.125,0.176$ and 0.535 , respectively. 
Relationships between the available $\mathrm{Cu}$ and fresh biomass of rape in different treatments

Table 6 shows linear regression models between the available $\mathrm{Cu}$ concentrations in soils (as independent variables) and biomass of rape in roots, stems, pod shells and rapeseeds (as dependent variable). The $\mathrm{Cu}$ available fractions were significantly related with the biomass of rapeseeds for $R$ was $0.895(P<0.05)$. All the coefficients in front of the available $\mathrm{Cu}$ content were negative. The biomass of roots, stems and pod shells exhibited weaker relations with the concentrations of $\mathrm{Cu}$ available fractions for $R$ was $0.719,0.857$ and $0.864(P>0.05)$, respectively.

The observed results in our research are in agreement with the earlier reports that $\mathrm{Cu}$ in roots had relatively good sensitivity to $\mathrm{Cu}$ pollution, while the aerial parts of rape may not directly reflect the phytotoxicity of $\mathrm{Cu}$ (Guan et al. 2011). Meanwhile, the results also suggested that $\mathrm{Cu}$ in exchangeable fractions made the greatest contributions on the accumulation of $\mathrm{Cu}$ in the roots of rape (Table 4). In the case of the paddy soils studied, the lack of correlation found for rape between $\mathrm{Cu}$ concentrations in roots and in the aerial parts, suggests that an analysis of the aerial parts would not be a good indicator of plant $\mathrm{Cu}$ uptake.

The linear regression analysis between the available $\mathrm{Cu}$ content in soil and $\mathrm{Cu}$ contents in root, stem, pod shell and rapeseed of rape showed that available $\mathrm{Cu}$ made the largest contribution on the accumulation of $\mathrm{Cu}$ in roots. The exchangeable fractions and available $\mathrm{Cu}$ played a more important positive role in $\mathrm{Cu}$ bioavailability due to the biggest positive number of its coefficient, thus was more associated to estimate the actual toxicity of $\mathrm{Cu}$ to plant in our case. It could be presumed that $\mathrm{Cu}$ in plants mostly came from direct absorption of available fractions in the soil. The contents of available fractions of $\mathrm{Cu}$ were higher than the sum of the exchangeable fractions, carbonatebound fractions and $\mathrm{Fe}-\mathrm{Mn}$ oxides-bound fractions, but lower than that of the first four fractions (data not shown), suggesting that available fractions of $\mathrm{Cu}$ could extract exchangeable, carbonate-bound, $\mathrm{Fe}-\mathrm{Mn}$ oxides-bound and a portion of stable organic-bound fractions. Compared to the residual fraction, carbonate-bound fraction and $\mathrm{Fe}-\mathrm{Mn}$ oxides-bound fraction and organic-bound fraction had a

Table 6 Linear regression analysis between the available $\mathrm{Cu}$ content in soil and biomass of rape root, stem, pod shell and rapeseed

\begin{tabular}{lll}
\hline Regression equation & $R$ value & Significance \\
\hline $\mathrm{Y}_{\text {root }}=-0.004 \mathrm{X}_{\text {available } \mathrm{Cu}}+4.785$ & 0.719 & 0.171 \\
$\mathrm{Y}_{\text {stem }}=-0.009 \mathrm{X}_{\text {available } \mathrm{Cu}}+8.533$ & 0.857 & 0.063 \\
$\mathrm{Y}_{\text {pod shell }}=-0.046 \mathrm{X}_{\text {available } \mathrm{Cu}}+34.702$ & 0.864 & 0.059 \\
$\mathrm{Y}_{\text {seed }}=-0.00013 \mathrm{X}_{\text {available } \mathrm{Cu}}+0.167$ & 0.895 & 0.040 \\
\hline
\end{tabular}

high potential to become bioavailable fraction, and therefore, they served as a potential nutrition pool to plants. If the proportions of these fractions changed, the capacity and mobility of heavy metals in soil would change (Zhou and Sun 2002; Zhou et al. 2004). In fact, the available fractions of $\mathrm{Cu}$ in soil are highly mobile. As the weakly bound fractions, such as carbonate-bound fraction and $\mathrm{Fe}-\mathrm{Mn}$ oxides-bound fraction, tend to resolve into available fractions. Therefore, the importance of these fractions should not be neglected.

\section{Factor analysis}

The factor analysis technique allows a considerable reduction in the number of variables and the detection of structure in the relationships, which would give information about the relation between soil and plant systems (Maiz et al. 2000). In the present study, factor analysis (FA) was performed by evaluation of principal components and computing the eigenvectors. Table 7 presents the eigenvalues, the percentage of variance and the cumulative percentage of variance associated with each other. The results revealed that the first two factors explain approximately $91.501 \%$ of total variance. Table 8 shows the loading of varimax rotated factor matrix for two-factor model. This is to be expected because these factors are extracted successively, each one accounting for as much of the remaining variance as possible. Table 8 displays the varimax rotated factor scores. Plots of factor loadings are shown in Fig. 3. The first and second factors explained $91.501 \%$ of the total variation. The first factor, explaining $70.405 \%$ of the total variation, exhibited a high positive factor loading on EXC and ROOT. The second factor, explaining $21.096 \%$ of the total variation, exhibited a high positive factor loading on SHELL and SEED. It indicated that the capacity of factor 1 was higher than factor 2 in explaining the total variation. The results of factor analysis suggested that exchangeable fractions contents (EXC), $\mathrm{Cu}$ contents in roots (ROOT), shells (SHELL) and seeds (SEED) had relatively good sensitivity to the Cu pollution. As the critical variables of factor 1, the exchangeable fraction contents (EXC) and $\mathrm{Cu}$ contents in roots (ROOT)

Table 7 Eigenvalues, percent of variance, cumulative percent of variance for the factor analysis of $\mathrm{Cu}$ content in soil and biomass of rape root, stem, pod shell and rapeseed

\begin{tabular}{llll}
\hline Factor & Eigenvalue & Variance $(\%)$ & Cumulative $(\%)$ \\
\hline 1 & 7.745 & 70.405 & 70.405 \\
2 & 2.321 & 21.096 & 91.501 \\
3 & 0.913 & 8.298 & 99.799 \\
4 & 0.022 & 0.201 & 100.000 \\
\hline
\end{tabular}


Table 8 Loading for varimax rotated factor matrix of two-factor model explaining $91.5 \%$ of the total variance

\begin{tabular}{lrr}
\hline Variable & Factor 1 & Factor 2 \\
\hline EXC & 0.996 & -0.011 \\
CAR & 0.988 & 0.112 \\
Fe-Mn & 0.817 & 0.577 \\
ORG & 0.799 & 0.600 \\
RES & 0.975 & -0.149 \\
TOTAL & 0.950 & 0.311 \\
AVAILABLE & 0.968 & 0.248 \\
ROOT & 0.996 & 0.019 \\
STEM & -0.001 & -0.525 \\
SHELL & -0.067 & 0.968 \\
SEED & 0.318 & 0.898 \\
\hline
\end{tabular}

$E X C$ exchangeable fractions, $C A R$ carbonate-bound fractions, $\mathrm{Fe}-\mathrm{Mn}$ $\mathrm{Fe}-\mathrm{Mn}$ oxides-bound fractions, $O R G$ organic-bound fractions, $R E S$ residual fractions, TOTAL total $\mathrm{Cu}$ content in soils, AVAILABLE available $\mathrm{Cu}, R O O T \mathrm{Cu}$ content in roots, STEM Cu content in stems, SHELL $\mathrm{Cu}$ content in pod shells, SEED Cu content in seeds

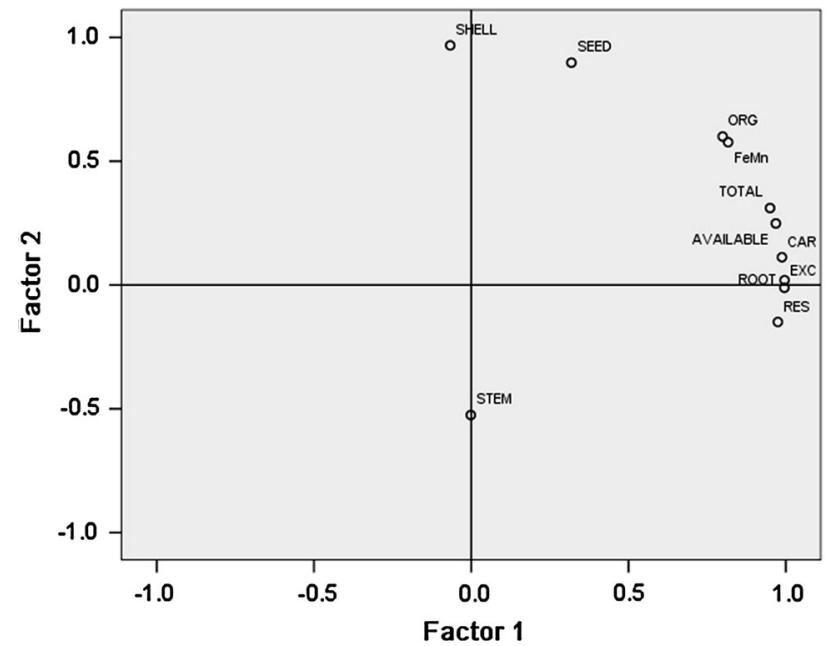

Fig. 3 Plots of variables on the first two axes extracted by factor analysis (with varimax rotation) of the data for different treatments

could be regarded as the best indicators for estimating the actual toxicity of $\mathrm{Cu}$ to rape. From Fig. 3, the variates loading heavily on axis I in the data analysis are those clearly associated with fractions contents of $\mathrm{Cu}$ in soils and $\mathrm{Cu}$ content in roots (EXC, CAR, RES and ROOT), while the variates loading heavily on axis II in this analysis are all related to $\mathrm{Cu}$ content in aerial parts (STEM and SHELL).

\section{Conclusion}

The present study demonstrated that the $\mathrm{Cu}$ mobility and its availability to the rape were highly dependent on the chemical fractions in the polluted paddy soils. The residual fractions accounted for the largest proportion of $\mathrm{Cu}$ in the unpolluted paddy soil; however, the Fe-Mn oxides-bound fractions and organic-bound fractions increased most rapidly with the increase of $\mathrm{Cu}$ addition. The exchangeable fractions played the most important role in controlling the $\mathrm{Cu}$ mobility and availability, which mainly associated to the $\mathrm{Cu}$ uptake by rape.

Low concentrations of $\mathrm{Cu}$ facilitated the growth of rape, but high concentrations of $\mathrm{Cu}$ obviously inhibited the growth of rape. Comparing with the accumulation in soil, uptake of $\mathrm{Cu}$ in rape was very low. There is an important restriction occurred in the internal transport of $\mathrm{Cu}$ from roots to aerial parts. The exchangeable fractions made the most contributions on $\mathrm{Cu}$ uptake by rape roots. The factor analysis results showed that the exchangeable fractions and $\mathrm{Cu}$ contents in roots could be regarded as the best indicators for estimating the actual toxicity of $\mathrm{Cu}$ to rape.

Bio-concentration factors of $\mathrm{Cu}$ in roots were greater than those in stems. Translocation factors of $\mathrm{Cu}$ in stems were all less than 1.00 in all treatments, and the ratios of rapeseeds/pods shell were less than 1.00. The translocation of $\mathrm{Cu}$ was restricted from pod shells to rapeseeds to avoid excessive $\mathrm{Cu}$-induced damage. Copper mainly accumulated in the underground parts of rape in our case.

Acknowledgments We are grateful to the chief editor and anonymous reviewers for illuminating comments. This research was mainly supported by "The Research culture Funds of Anhui Normal University" (2013rcpy40), "Foundation of Provincial Key Laboratory of Conservation and Utilization for Important Biological Resource in Anhui", Foundation of Key Lab Biot Environm \& Ecol Safety Anhui Prov and Starting Foundation of Anhui Normal University for Doctors.

$\begin{array}{ll}\text { Abbreviations } \\ \text { BCF } & \text { Bio-concentration factor } \\ \text { CAR } & \text { Carbonate-bound fractions } \\ \mathrm{Cu} & \text { Copper } \\ \text { EXC } & \text { Exchangeable fractions } \\ \text { FA } & \text { Factor analysis } \\ \text { FDC } & \text { Fractionation distribution coefficient } \\ \text { Fe-Mn } & \text { Fe-Mn oxides-bound fractions } \\ \text { ORG } & \text { Organic-bound fractions } \\ \text { RES } & \text { Residual fractions } \\ \text { TF } & \text { Translocation factor }\end{array}$

\section{References}

Ahumada I, Gudenschwager O, Carrasco MA, Castillo G, Ascar L, Richter P (2009) Copper and zinc bioavailabilities to ryegrass (Lolium perenne L.) and subterranean clover (Trifolium subterraneum L.) grown in biosolid treated Chilean soils. J Environ Manage 90:2665-2671 
Ali I, Khan TA, Hussain I (2011) Treatment and remediation methods for arsenic removal from the ground water. Int J Environ Eng 3:48-71

Bhattacharyya P, Chakraborty A, Chakrabarti K, Tripathy S, Powell MA (2006) Copper and zinc uptake by rice and accumulation in soil amended with municipal solid waste compost. Environ Geol 49:1064-1070

Brun LA, Maillet J, Hinsinger P, Pepin M (2001) Evaluation of copper availability to plants in copper-contaminated vineyard soils. Environ Pollut 111:293-302

Cao ZH, Hu ZY (2000) Copper contamination in paddy soils irrigated with wastewater. Chemosphere 41:3-6

Cattani I, Fragoulis G, Boccelli R, Capri E (2006) Copper bioavailability in the rhizosphere of maize (Zea mays L.) grown in two Italian soils. Chemosphere 64:1972-1979

Chaignon V, Sanchez-Neira I, Herrmann P, Jaillard B, Hinsinger P (2003) Copper bioavailability and extractability as related to chemical properties of contaminated soils from a vine-growing area. Environ Pollut 123:229-238

Chaignon V, Quesnoit M, Hinsinger P (2009) Copper availability and bioavailability are controlled by rhizosphere $\mathrm{pH}$ in rape grown in an acidic Cu-contaminated soil. Environ Pollut 157:3363-3369

Clemens S, Palmgren MG, Krämer U (2002) A long way ahead: understanding and engineering plant metal accumulation. Trends Plant Sci 7:309-315

Feigl G, Kumar D, Lehotai N, Tugyi N, Molnár Á, Ördög A, Szepesi Á, Gémes K, Laskay G, Erdei L, Kolbert Z (2013) Physiological and morphological responses of the root system of Indian mustard (Brassica juncea L. Czern.) and rapeseed (Brassica napus L.) to copper stress. Ecotox Environ Safety 94:179-189

Fuentes A, Llorens M, Saez J, Soler A, Aguilar MI, Ortuno JF, Meseguer VF (2004) Simple and sequential extractions of heavy metals from different sewage sludges. Chemosphere 54:1039-1047

Grzebisz W, Kocialkowski WZ, Chudzinski B (1997) Copper geochemistry and availability in cultivated soils contaminated by a copper smelter. J Geochem Explor 58:301-307

Guan TX, He HB, Zhang XD, Bai Z (2011) Cu fractions, mobility and bioavailability in soil-wheat system after $\mathrm{Cu}$-enriched livestock manure applications. Chemosphere 82:215-222

Guo GL, Zhou QX (2005) Fractionation distribution and bioactivity of heavy metals in contaminated phaiozem. Environ Chem 24(4):383-388

Herrero EM, López-Gonzálvez A, Ruiz MA, Lucas-García JA, Barbas C (2003) Uptake and distribution of zinc, cadmium, lead and copper in Brassica napus var. oleífera and Helianthus annus grown in contaminated soils. Int J Phytorem 5:153-167

Huang YZ, Hu Y, Liu YX (2009) Combined toxicity of copper and cadmium to six rice genotypes (Oryza sativa $\mathrm{L}$.). J Environ Sci China 21:647-653

Johansson L, Xydas C, Messios N, Stoltz E, Greger M (2005) Growth and $\mathrm{Cu}$ accumulation by plants grown on $\mathrm{Cu}$ containing mine tailings in Cyprus. Appl Geochem 20:101-107

Kabala C, Singh RR (2001) Fractionation and mobility of copper, lead, and zinc in soil profiles in the vicinity of a copper smelter. J Environ Qual 30:485-492

Lexmond ThM (1980) The effect of soil $\mathrm{pH}$ on copper toxicity to forage maize grown under field conditions. Netherlands J Agr Sci 28:164-184

Lucho-Constantino CA, Prieto-García F, Del Razo LM, RodríguezVázquez R, Poggi-Varaldo HM (2005) Chemical fractionation of boron and heavy metals in soils irrigated with wastewater in central Mexico. Agr Ecosyst Environ 108:57-71

Luo YM, Jiang XJ, Wu LH, Song J, Wu SC, Lu RH, Christie P (2003) Accumulation and chemical fractionation of $\mathrm{Cu}$ in a paddy soil irrigated with $\mathrm{Cu}$-rich wastewater. Geoderma 115:113-120

Ma LQ, Rao GN (1997) Chemical fractionation of cadmium, copper, nickel, and zinc in contaminated soils. $J$ Environ Qual 13:372-376

Maiz I, Arambarri I, Garcia R, Millan E (2000) Evaluation of heavy metal availability in polluted soils by two sequential extraction procedures using factor analysis. Environ Pollut 110:3-9

Marcato CE, Pinelli E, Cecchi M, Winterton P, Guiresse M (2009) Bioavailability of $\mathrm{Cu}$ and $\mathrm{Zn}$ in raw and anaerobically digested pig slurry. Ecotox Environ Safe 72:1538-1544

Michaud AM, Bravin MN, Galleguillos M, Hinsinger P (2007) Copper uptake and phytotoxicity as assessed in situ for durum wheat (Triticum turgidum durum L.) cultivated in $\mathrm{Cu}-$ contaminated, former vineyard soils. Plant Soil 298:99-111

Rodríguez L, Ruiz E, Alonso-Azcárate J, Rincn J (2009) Heavy metal distribution and chemical fractionation in tailings and soils around $\mathrm{a} \mathrm{Pb}-\mathrm{Zn}$ mine in Spain. $\mathrm{J}$ Environ Manage 90:1106-1116

Salomons W, Stigliani WM (1995) Biogeodynamics of pollutants in soils and sediments: risk assessment of delayed and non-linear responses. Springer, Berlin, p 352

Seregin IV, Kozhevnikova AD (2006) Physiological role of nickel and its toxic effects on higher plants. Russ J Plant Physiol 53:257-277

Silveira ML, Alleoni LRF, O'Connor GA, Chang AC (2006) Heavy metal sequential extraction methods-a modification for tropical soils. Chemosphere 64:1929-1938

Tao S, Chen YJ, Xu FL, Cao J, Li BG (2003) Changes of copper fractionation in maize rhizosphere soil. Environ Pollut 122:447-454

Tessier A, Campbell PGC, Bisson M (1979) Sequential extraction procedure for the fractionation of particulate trace-metals. Anal Chem 51:844-851

Torri S, Lavado R (2009) Plant absorption of trace elements in sludge amended soils and correlation with soil chemical fractionation. J Hazard Mater 166:1459-1465

Yang MJ, Yang XE, Romheld V (2002) Growth and nutrient composition of Elsholtzia splendens Nakai under copper toxicity. J Plant Nutr 25:1359-1375

Yang YM, Nan ZR, Zhao ZJ, Wang SL, Wang ZW, Wang X (2011) Chemical fractionations and bioavailability of cadmium and zinc to cole (Brassica campestris L.) grown in the multi-metals contaminated oasis soil, northwest of China. J Environ Sci China 23(2):275-281

Yang YM, Nan ZR, Zhao ZJ, Wang ZW, Wang SL, Wang X, Jin WQ, Zhao CC (2011). Bioaccumulation and translocation of cadmium in cole (Brassica campestris L.) and celery (Apium graveolens) grown in the polluted oasis soil, Northwest of China. J Environ Sci China 23(8):1368-1374

Yoon J, Cao XD, Zhou QX, Ma LQ (2006) Accumulation of Pb, Cu, and $\mathrm{Zn}$ in native plants growing on a contaminated Florida site. Sci Total Environ 368:456-464

Zemberyova M, Zwaik AAH, Farkasovska I (1998) Sequential extraction for the fractionation of some heavy metals in soils. J Radioanal Nucl Chem 229:56-71

Zhang XH, Lin AJ, Gao YL, Reid RJ, Wong MH, Zhu YG (2009) Arbuscular mycorrhizal colonisation increases copper binding capacity of root cell walls of Oryza sativa L. and reduces copper uptake. Soil Biol Biochem 41:930-935 
Zhou QX, Sun TH (2002) Effects of chromium (VI) on extractability and plant uptake of fluorine in agricultural soils of Zhejiang Province, China. Water Air Soil Poll 133:145-160
Zhou QX, Sun FH, Guo GL, Sun TH (2004) Influence of acetochlor on $\mathrm{Pb}$ fractions and their bioavailability in phaiozem of northeast China. Chin J Appl Ecol 15(10):1883-1886 